\title{
РАСПРЕДЕЛЕНИЕ ВЕРТЕБРАТ В РАЗНОФАЦИАЛЬНЫХ ОТЛОЖЕНИЯХ СИЛУРА СЕВЕРНОЙ ПРИБАЛТИКИ
}

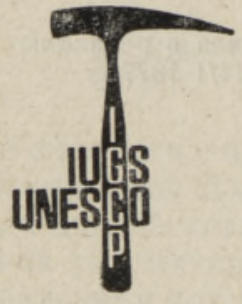

Проект «Экостратиграфия»

В течение последнего десятилетия данные о распространении вертебрат в силуре Эстонии и Западной Латвии значительно пополнились благодаря систематическому изучению керна буровых скважин и растворению пород для извлечения остатков позвоночных. Если литература по стратиграфическому распространению позвоночных довольно обширна (Mark-Kurik, 1969; MarkKurik, Noppel, 1970; Кальо, ред., 1970; Каратаюте-Талимаа, 1970, 1977; Гайлите, Ульст, 1974; Эйнасто и др., 1977), то данные о фациальной приуроченности вертебрат оставались до сих пор почти вне освещения.

Долгое время господствовало представление о том, что силурийские позвоночные обитали в прибрежной зоне моря в ненормальноморских условиях, в частности, в литоральной зоне, в лагунах и в приустьевой части рек (Hoppe, 1931; Denison, 1956; Обручев, 1964; и др.). Наши исследования показывают, что ареал распространения вертебрат был гораздо шире.

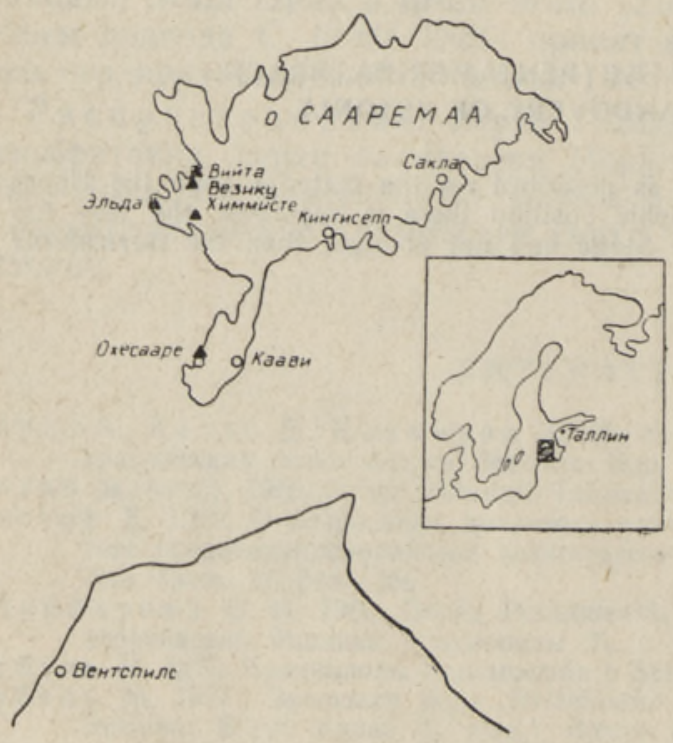

Материалом для данного сообщения послужили послойно изученные разрезы буровых скважин Сакла, Кингисепп, Oхесааре, Каави (571), Вентспилс и обнажений Вийта, Везику, Эльда, Химмисте и Охеcaаpe (рис. 1), из которых обработано около 400 проб с определением позвоночных (Т. Мярсс) и сделан фациальный анализ отложений (Р. Эйнасто). Стратиграфическое расчленение разрезов проведено согласно схеме А. Аалоэ и др. (1976). Следует обратить внимание на то, что коли-

Рис. 1. Схема расположения изученных скважин (кружки) и обнажений (треугольники). 


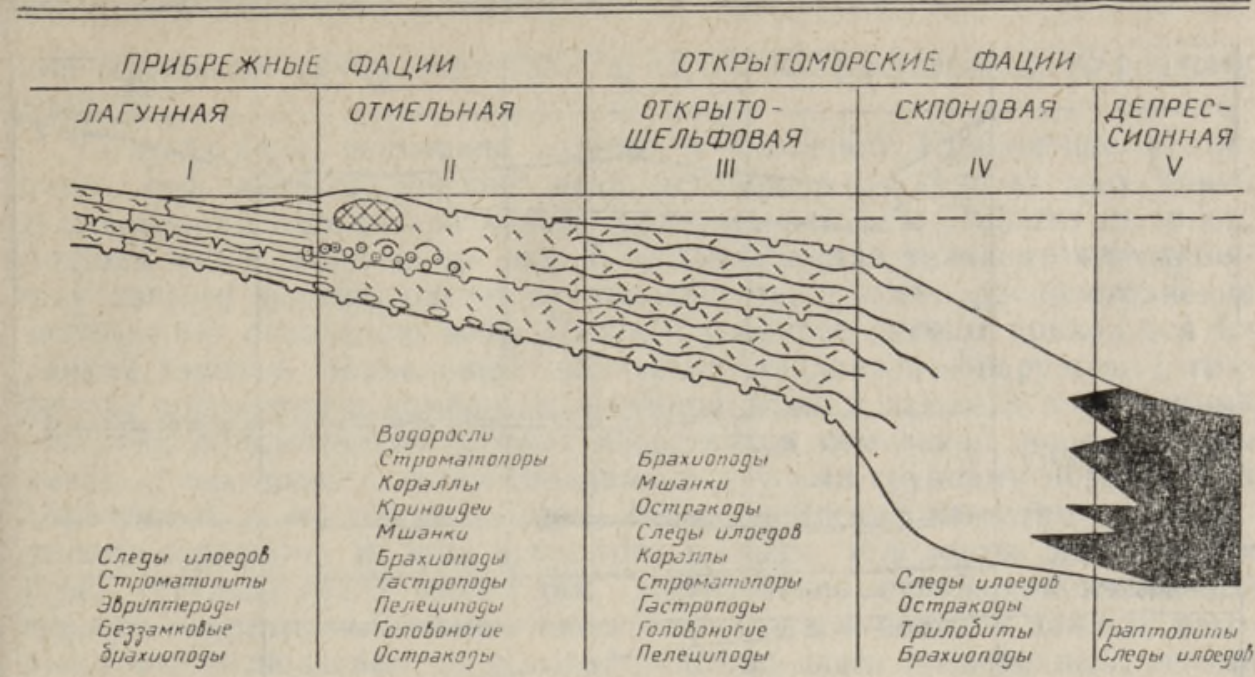

Рис. 2. Схема фациальной зональности Палеобалтийского бассейна в силуре по Х. Нестору и Р. Эйнасто (1977). Условные обозначения см. на рис. 3.

чество проб из отложений разных фациальных зон неодинаково (данные из депрессионной зоны отсутствуют).

Представленный ниже обзор распределения остатков позвоночных с учетом фациального характера вмещающих их пород сделан на уровне макрофаций, т. е. основных фациальных зон севернсго борта Палеобалтийского бассейна, выявленных при комплексном изучении литологии отложений и ископаемой фауны (Кальо, ред., 1970; Эйнасто, Нестор, 1973). Седиментологическая интерпретация отложений выделенных фациальных зон дается согласно фациальной модели этого периконтинентального (краевого) бассейна (Нестор, Эйнасто, 1977). Микрофациальные различия пород в данной статье не рассматриваются, хотя они могут дать ценную дополнительную информацию об условиях обитания и захоронения вертебрат.

Фациальные зоны силурийского Балтийского бассейна следующие (рис. 2): 1. Л агунная (зона приливной, равнины) с тиховодными условиями, где образовались микрослойчатые седиментационные глинистые доломиты со специфической ассоциацией организмов (строматолитов, эвриптерид и т. д.). 2. Отмельная (зона волнения) с чистыми зернистыми «промытыми» известковыми осадками и многочисленными остатками сессильного бентоса, скоплениями вымерших раковин и органогенными постройками. Зона представлена обломочными, биоморфными, детритовыми, сгустковыми, биогермными известняками и характеризуется частыми поверхностями перерыва. 3. Зона открытого шельфа простирается от волнового базиса (иловой линии) до внешнего края стабильного шельфа, где в субтурбулентных условиях отлагались смешанные илисто-зернистые глинисто-карбонатные осадки и обитала очень разнообразная по групповому и видовому составам раковинная фауна. Этой зоне свойственны илисто-детритовые комковатые известняки. 4. С клоно в а я - переходная от шельфа до глубоководной части моря зона с тиховодными условиями и илистыми карбонатнотерригенными отложениями однородного состава. Это зона непрерывной седиментации и максимальных мощностей. 5. Д епрессионна я глубоко погруженная часть бассейна с однообразными глинами и битуминозными граптолитовыми аргиллитами без бентоса. 
KAABH (571)

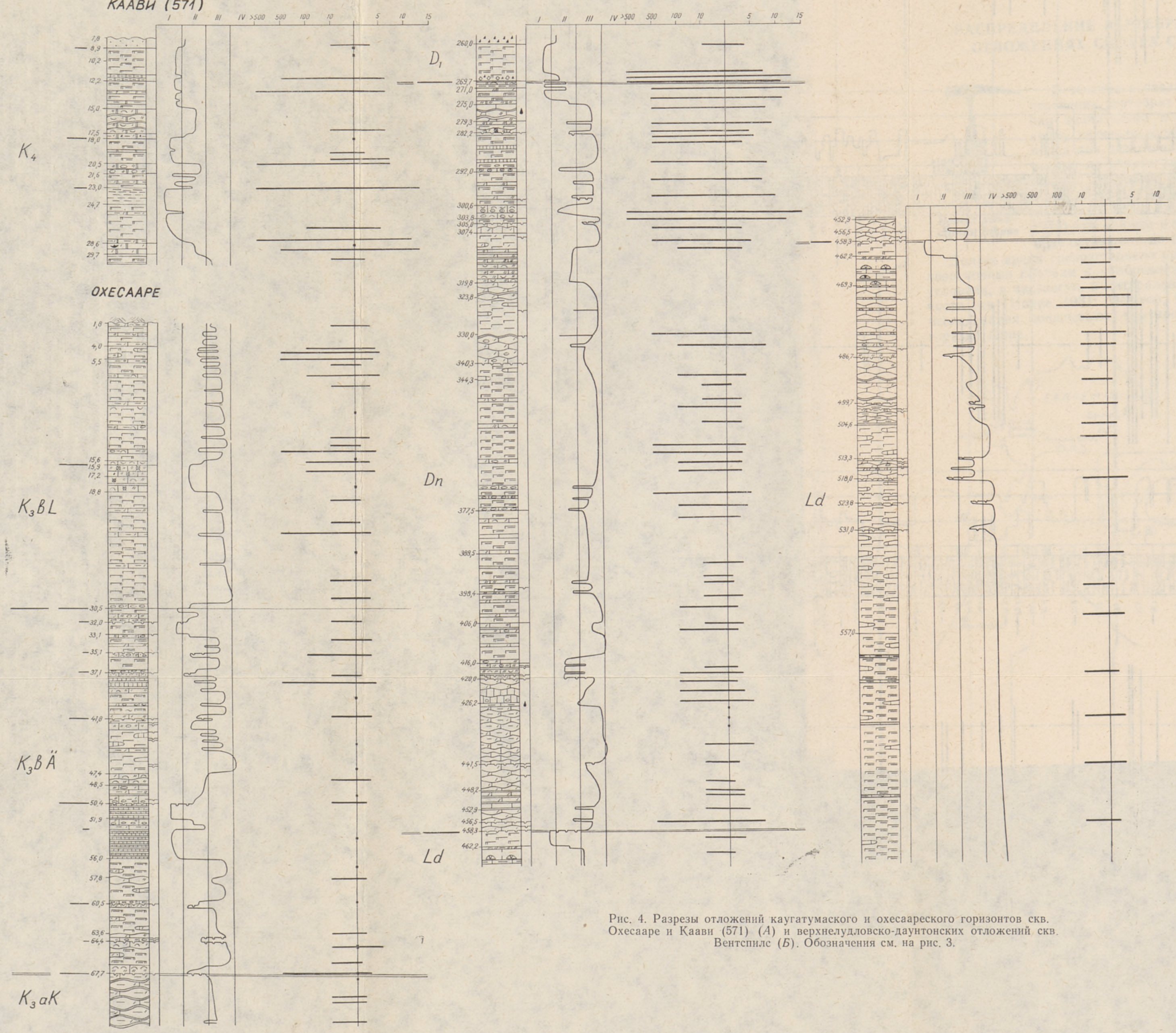




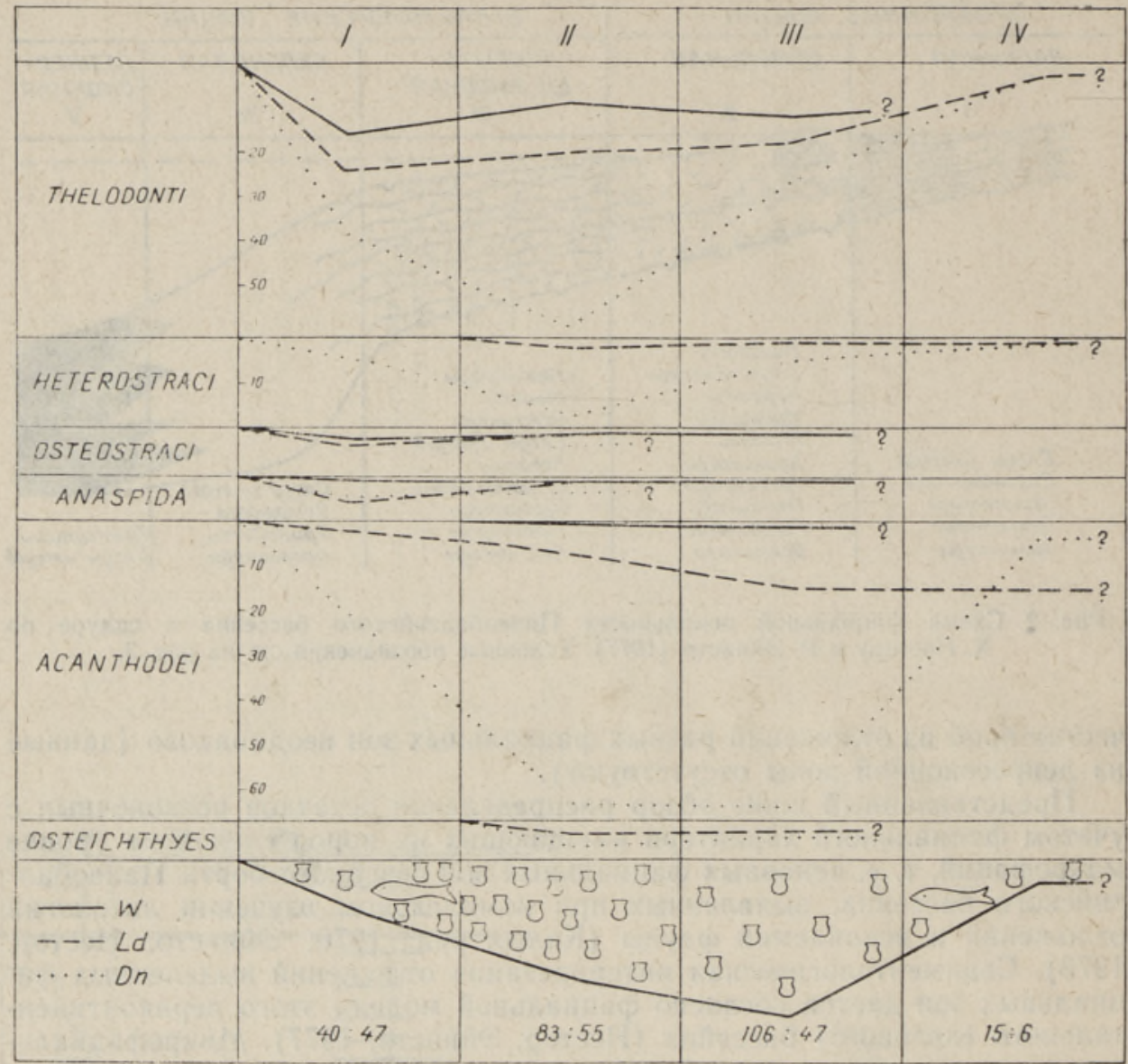

Рис. 5. Распределение позвоночных по фациальным зонам. По вертикали - количество видов в пробах из отдельных фациальных зон по ярусам. Количественные данные на кривой по телодонтам, гетеростракам, акантодам и остеихтидам в даунтоне уменьшены в три раза. Внизу цифрами показано соотношение проб, содержащих остатки вертебрат, к пустым пробам.

Фауна позвоночных силура Северной Прибалтики представлена примерно 45 видами. (статки вертебрат найдены начиная с верхнего венлока и кончая последним стратиграфическим подразделением силура (рис. 3 и 4). Однако при сопоставлении данных проб с фациальными кривыми (на рис. 3 и 4 правее колонки) бросается в глаза четкая закономерность: в верхнем венлоке и нижнем лудлове (до химмистеских слоев паадлаского горизонта) вне зависимости от фаций остатки вертебрат содержаться лишь в $25 \%$ проб. Поскольку этот интервал разреза не отличается ни богатством видового состава, ни количеством экземпляров, то для выявления причинной связи между условиями среды и составом ассоциаций необходим дальнейший обстоятельный анализ. В верхнем лудлове количество проб с остатками вертебрат увеличивается до $75 \%$, а в даунтоне достигает $86 \%$, причем видовой состав вертебрат становится все разнообразнее и количество особей возрастает.

Для выяснения особенностей распределения отдельных групп позвоночных по зонам мы суммировали их находки по вышеотмеченным фациям. Оказалось, что фациальная обстановка влияет на взаимоотноше- 
ния отдельных групп вертебрат и на их распространение по-разному (рис. 5).

Телодонты, появление которых в Северной Прибалтике совпадает с серединой венлокского века, установлены в первых трех зонах. В маазиских слоях яагарахуского горизонта найдены Thelodus sp. indet., Logania taiti?, Logania sp. nov. В лудлове состав телодонтов пополняется новыми видами, растет их численность, а ареал распространения захватывает склоновую зону. Пышное развитие группы приходится на ранний даунтон. Наибольшее количество телодонтов обнаружено в глинистых доломитах и домеритах лагунной зоны, а также в маломощных прослоях обломочно-детритовых известняков отмельной зоны, где они вместе с акантодами, гетеростраками и другими группами позвоночных образуют т. н. костеносные слои. Такие скопления известны в охесаареском горизонте. В зоне открытого шельфа телодонты встречаются реже, уступая место акантодам. Даунтонские отложения склоновой зоны на территории Әстонии почти не развиты и поэтому данные, которыми мы располагаем по распространению здесь позвоночных, весьма малочисленны. В отложениях открытого шельфа и материкового склона найдены в небольшом количестве Thelodus parvidens, T. traquairi, $T$. pugniformis, T. sculptilis, T. admirabilis sp. nov. и Logania cuneata.

Гетеростраки появляются в Әстонии начиная с верхней половины лудлова (с удувереских слоев паадлаского горизонта). Самым древним гетеростраком здесь является Archegonaspis sp. Его остатки встречаются, хотя и редко, во всех зонах, исключая лагунную и депрессионную. Однако в основании даунтона они прослеживаются и в отложениях лагунной зоны. Наибольшее количество находок гетеростраков приходится на отмельные отложения верхнего даунтона. Чаще других здесь встречается Strosipherus indentatus. Целые панцири Tolypelepis undulata найдены в зоне открытого шельфа и в склоновой зоне охесаареского горизонта.

Остеостраки и ан аспиды начинают встречаться с венлока в основном в лагунных и отмельных отложениях. В сторону открытого моря их численность постепенно уменьшается (материалы о склоновой зоне отсутствуют). К лагунной зоне приурочены известные местонахождения остеостраков Вийта и Химмисте, а также новое венлокское местонахождение целых панцирей трематаспид на береговом обрыве Эльда (рис. 1), где обнажаются доломиты куусныммеских слоев роотсикюлаского горизонта. Видовой состав остеостраков и анаспид в силуре Эстонии нуждается в уточнении.

Древнейшие а кантоды в виде отдельных чешуй найдены на территории Эстонии в прослоях глинистых доломитов отмельной зоны в яагарахуском горизонте (верхний венлок). Выше по разрезу их наличие установлено в комковатых известняках открытого шельфа. В лудлове область распространения акантод расширяется, охватывая лагунную и склоновую зоны. Максимальное их количество приурочено к отложениям отмельной зоны и зоны открытого шельфа даунтона, где они представлены родами Nostolepis, Gomphonchus и Poracanthodes.

Из остеихтид известны две формы, происходящие из отложений отмельной и открытошельфовой зон лудлова и даунтона. В лудловских отложениях присутствует Andreolepis hedei, а в даунтонских - Lophosteus superbus.

Из сказанного следует, что в силуре Северной Прибалтики наиболее часто встречаются группы Thelodonti и Acanthodei (рис. 6). Телодонты почти на всех стратиграфических уровнях более тяготеют к отложениям лагунной зоны. В отмельной зоне их количество несколько уменьшается 


\begin{tabular}{|c|c|c|c|c|c|}
\hline & & Лагунная & Отмельная & $\begin{array}{c}\text { Отікрыто- } \\
\text { шельФовая }\end{array}$ & Склоновая \\
\hline \multirow{3}{*}{ 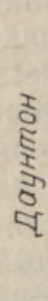 } & $K_{4}$ & $(T A C) H$ & ACTHOC & $\mathrm{AcTO}_{\mathrm{S} H}$ & - \\
\hline & $K_{3} b$ & & $A C T H$ & ACTH & - \\
\hline & $K_{3} a$ & TACHOA & $\mathrm{TACH}(O A)$ & AcTH & $(A c T) H$ \\
\hline $\begin{array}{l}\text { న్ } \\
\text { న్ } \\
\text { న్ }\end{array}$ & $K_{2}$ & $T(A O) A C$ & $\mathrm{TACOsH}(O A)$ & $\mathrm{TACOsH}$ & AcTH \\
\hline ริ & $K_{1}$ & TOA & $T(O A)$ & $T(O A C)$ & - \\
\hline$\infty$ & $J_{2}$ & TI & TAC & $T(O A)$ & - \\
\hline
\end{tabular}

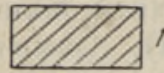

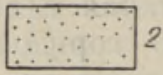

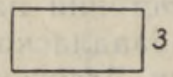

Рис. 6. Взаимоотношения отдельных групп позвоночных по отдельным фациальным зонам: T - Thelodonti, H - Heterostraci, O - Osteostraci, A Anaspida, Ac - Acantho. dei, Os - Osteichthyes; 1 - присутствуют только телодонты; 2 - телодонты превалируют над остеостраками и анаспидами; 3 - телодонты превалируют над акантодами; 4 акантоды превалируют над телодонтами $(a)$, тех и других поровну (б); в скобках отмечены группы, которые найдены в одинаковых количествах.

и выше курессаареского горизонта руководящее значение приобретают уже акантоды, хотя суммарное количество и тех и других находок здесь одинаково. Если в отложениях зоны открытого шельфа венлокского и лудловского веков телодонты еще преобладают над акантодами, то в даунтоне явный перевес имеют акантоды. Последнее высказывание содержит некоторую долю сомнения относительно находок представителей этих групп из отложений склоновой зоны лудловского и раннедаунтонского возрастов, поскольку мы располагаем отсюда очень малым количеством образцов.

Исследованный нами материал дал возможность сделать ряд выводов о сохранности, местах обитания и захоронения позвоночных.

Остатки позвоночных в лагунной зоне не имеют следов окатывания. В этой зоне найдены целые экземпляры Phlebolepis и панцири остеостраков. Можно полагать, что бесчелюстные населяли прежде всего тиховодную часть моря, где были благоприятными условия как для обитания, так и для захоронения.

К отмельной зоне приурочены обильные скопления чешуй и обломков скелетов агнат и рыб, порой образующих т. н. костеносные слои. Остатки здесь, как правило, окатаны. В этой зоне фрагментов монолитных панцирей остеостраков и гетеростраков значительно меньше по сравнению с лагунной и открытошельфовой зонами. Эта часть моря была, по-видимому, и местом обитания вертебрат. Однако надо учитывать, что в турбулентных гидродинамических условиях в процессе повторного переотложения осадочного материала некоторая доля последних могла быть привнесена сюда из соседних фациальных зон.

В отложениях зоны открытого шельфа в условиях непрерывной седиментации и малой гидродинамической активности воды чешуи и другие мелкие части скелета вертебрат встречаются уже не скоплениями, a разбросанно. Не исключено, что частичный привнос остатков позвоночных из прибрежной зоны имел место и здесь.

В склоновой зоне, на пологом материковом склоне, где процесс осад- 
конакопления происходил особенно активно, а движение воды было слабоинтенсивным, привнос материала из других зон маловероятен. Здесь встречаются небольшие захоронения и чешуй, и целых панцирей агнат, как и в тиховодной лагунной зоне. Данные по склоновой зоне требуют еще уточнения.

Итак, можно сказать, что из лагунной зоны происходят целые экземпляры (иногда в виде скоплений) и отдельные элементы скелетов вертебрат; в отложениях отмельной зоны встречаются только отдельные элементы скелетов, часто в виде скоплений; в отложениях открытого шельфа изолированные скелетные элементы обычно рассеянны; в мергелях склоновой зоны встречаются рассеянно как целые панцири позвоночных (правда, очень редко), так и отдельные элементы скелетов.

В результате проведенных исследований выяснилось, что фациальная амплитуда распространения силурийских позвоночных далеко выходит за пределы литоральной зоны, и поэтому вертебраты могут быть успешно применены для корреляции разнофациальных отложений морского происхождения. Более того, позвоночные могут сыграть большую роль при сопоставлении монотонных доломитовых толщ, где встречаются только вертебраты и конодонты, а представители нормальноморской раковинной фауны либо не существовали, либо они были уничтожены вторичными процессами (Эйнасто и др., 1977).

Авторы выражают благодарность Л. П. Карпицкой (Управление геологии ЛатССР) и Э. Кала (Управление геологии СМ ЭССР) за предоставленную возможность изучить керн скв. Вентепилс и Каави (571), а также коллегам из института за ценные советы.

\section{Л И Т Е Р А Т Р А}

А алоэ А., Кальо Д., Кла ам анн Э., Нестор Х., Эйн асто Р. 1976. Стратиграфическая схема силура Эстонии. Изв. АН ЭССР, Хим. Геол., 25, 38-45.

Г а йли те Л. К., У льст Р. Ж. 1974. Зональные подразделения верхнего силура в Латвии. В кн.: Региональная геология Прибалтики. Рига, с. 38-44.

К а льо Д. (ред.). 1970. Силур Эстонии. Таллин, 343 с.

К а р а т а ют е-Т а ли м а а В. Н. 1970. Ихтнофауна даунтона Литвы, Эстонии и Северного Тимана. В кн.: Палеонтология и стратиграфия Прибалтики и Белоруссин. Сб. 2. Вильнюс, с. $33-66$.

К а р а т а ют е - Т а ли м а а В. Н. 1977. Телодонты силура и девона СССР и Шпицбергена. Вильнюс (в печати).

Н е с т о р Х. Э., Э й н а с то Р. Э. 1977. Фациально-седиментологическая модель силурийского Палеобалтийского периконтинентального бассейна. В кн.: Фации и фауна силура Прибалтики. Таллин, с. 89-121.

О б р у ч е в Д. В. (ред.). 1964. Основы палеонтологии. Бесчелюстные, рыбы. М., 523 с.

Эйн а с то Р. Э., Н ест о Р Х. Э. 1973. Общая схема фациальной зональности Балтийского бассейна в силуре и ее палеогеографо-седиментологическая интерпретация, В кн.: Фации и геохимия карбонатных отложений. Л.-Таллин, с. $38-40$.

Э й н с т О Р., М я р с с Т., К а л а Э. 1977. Стратиграфическое расчленение верхневенлокско-даунтонской доломитовой толщи в разрезах Сакла, Варбла и Кихну. Изв. АН ЭССР, Хим. Геол., 26, 38-45.

De n is o n, R. H. 1956. A review of the habitat of the earliest vertebrates. Fieldiana: Geology, 11. No. 8, 359-457.

Hop p e K.-H. 1931. Die Coelolepiden und Acanthodier des Obersilurs der Insel Ösel. Ihre Paläobiologie und Paläontologie. Palaeontographica, 76, 58.

Mark-Kurik E. 1969. Distribution of vertebrates in the Silurian of Estonia. Lethaia, $2,145-152$.

Mark-Kurik E., Noppel T. 1970. Additional notes on the distribution of vertebrates in the Silurian of Estonia. ENSV TA Toimet., Keem. Geol., 19, 171173. 
Tiiu MARSS, R. EINASTO

\section{SILURI SELGROOGSETE JAOTUMUSEST PÖHA-BALTI BASSEINI FATSIAALSETES SETETES}

Viiest puursüdamikust ja viiest paljandist vōetud ligikaudu 400 kivimiproovi analüüsi tulemusena on artiklis esitatud siluri agnaatide ja kalade skeletielementide jaotumuse iseloomustus erinevates fatsiaalsetes vööndites ning tehtud järeldusi selgroog. sete eluala, säilivuse ja mattumise kohta.

Tiï MARSS, R. EINASTO

\section{DISTRIBUTION OF VERTEBRATES IN DEPOSITS OF VARIOUS FACIES IN THE NORTH BALTIC SILURIAN}

Vertebrate fauna of the North Baltic Silurian is represented by about 45 species. Variability and occurrence of these taxa in deposits of various ages and facies are different. To estimate the role of vertebrates in Silurian stratigraphy and paleogeography correctly, the belonging of vertebrates to the determined facies was studied in 400 samples.

It became evident that more freguent vertebrate groups in the North Baltic Silurian are Thelodonti and Acanthodei. Thelodonts are more characteristic of lagoonal belt deposits throughout the whole stratigraphic sequence. In shoal belt the amount of thelodonts somewhat decreases; in the Post-Kuressaare age they lose their leading position as compared with acanthodians, although the total quantities of thelodont and acanthodium finds in this belt are the same. In open-shelf belt deposits of the Wenlockian and Ludlovian ages thelodonts still prevail, while in the Downtonian acanthodians are evidently in the majority. This conclusion is valid, with certain conditionality, for the groups in the deposits of the slope belt of Ludlovian and Early-Downtonian ages.

The material at our disposal enabled to reach some conclusions concerning the preservation, burial and habitat of vertebrates.

Vertebrate remains in the lagoonal belt are not abraded. In the same belt there have been found articulated specimens of Phlebolepis and shields of osteostracans. We can presume that vertebrates lived first of all in this low-energy part ot the sea, and here were also more suitable conditions for their burial.

In the shoal belt, the buried scales and skeletal fragments of agnathans and fishes sometimes occur in great quantities, forming so-called "bone-beds". Here the remains are often abraded. In this belt the fragments of osteostracans and heterostracans with intact shields are rarer in comparison with the lagoonal and open-shelf belts. This part of the sea was obviously also the vertebrate habitat. But it should be kept in view that in turbulent hydrodynamical conditions, by redeposition of sediments and vertebrate remains, a certain amount of the remains has evidently been transferred from neighbouring facies belts.

In open-shelf subturbulent environment, characterized by relatively continuous sedimentation, scales, and other small skeletal parts of vertebrates are scattered, and do not form accumulations. In this belt a partial influx of remains from the near-shore belt can also be supposed.

In the slope belt, on a gentle continental slope, sedimentation was more intensive whereas water movement was limited. Here scales as well as articulated heterostracan shields are buried in small amounts, like in the lagoonal low-energy belt. The influx of vertebrate remains from other belts is less probable. Data on the slope belt are still scarce and demand further study.

In summary it can be said that from the lagoonal belt come articulated specimens (sometimes as accumulations) and isolated skeletal elements of vertebrates; in deposits of the shoal belt only isolated skeletal elements can be met, often as accumulations; in open-shelf deposits the isolated skeletal elements are usually scattered; in marls of the slope facies belt rare articulated heterostracan shields occur as well as isolated skeletal elements.

In the result of the investigations it became evident that the distribution of Silurian vertebrates is not restricted to the tidal flat, and vertebrates can successfully be used for the correlation of marine deposits of various facies. Besides, vertebrates are of particular significance in the correlation of monotonous dolomitic rocks, in which the representatives of normal marine shelly fauna are missing or have been destroyed by post-depositional processes. 